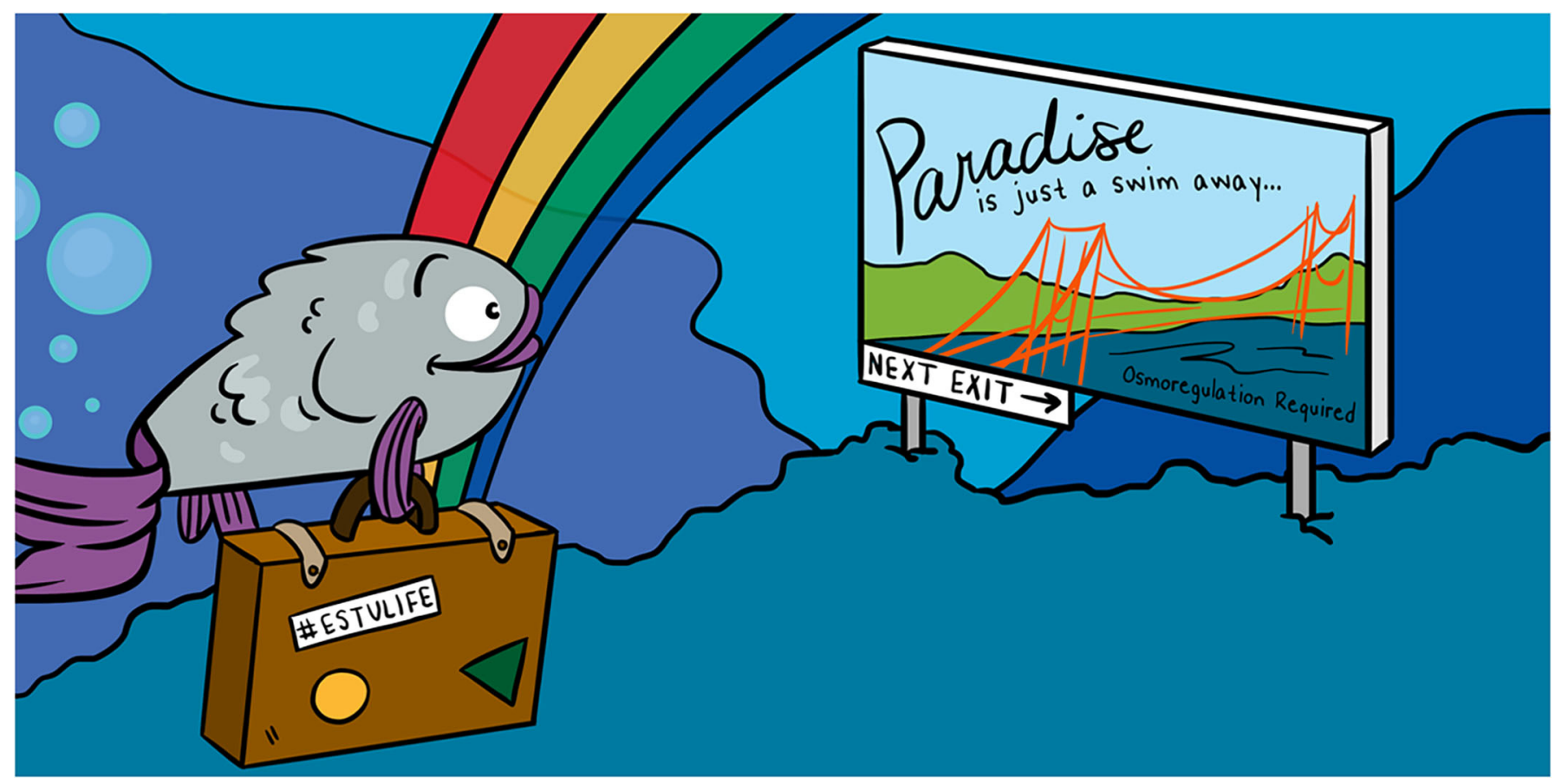

\title{
ESTUARIES, A HAPPY PLACE FOR FISH
}

\section{Pedro Morais ${ }^{1 *}$ and Ester Dias ${ }^{2}$}

${ }^{1}$ CCMAR-Centre of Marine Sciences, University of Algarve, Faro, Portugal

${ }^{2}$ CIIMAR-Interdisciplinary Centre of Marine and Environmental Research, University of Porto, Porto, Portugal

\section{YOUNG REVIEWER:}

FRESIA

AGE: 11
Anchovies, salmon, sardines, gobies, mullets, flounder, bass, barbels, eels, shad, and even sharks-what do they have in common? Well, at certain points in their lives you may find them in estuaries, the final sections of rivers before they meet the ocean. Some fish live in estuaries their entire lives. However, some fish species prefer living in the freshwater parts of estuaries, others only live close to the ocean, and a few others spread throughout the estuary. Some species prefer living close to the bottom, some in marshes, and some constantly swim around in the estuary. Some prefer eating other fish, while other species like worms, or insects, or microscopic animals. Unfortunately, many estuarine species are in danger, and all because of humans. In this article, we will tell you why estuaries are such special places for fish and describe some of the species that call the San Francisco Estuary their home.

\section{FISH SUPERPOWERS}

Have you noticed that fish can be found almost everywhere that you can find water? There are fish living in the deepest part of the ocean, 


\section{OSMOREGULATION}

The ability to regulate and maintain the right amount of water, nutrients, and salts inside cells.

\section{TIDES}

Tides exist because the moon acts as a magnet causing the rise and fall movement of water in estuaries, coastal lagoons, and along the ocean shores.

HIGH TIDE/LOW

TIDE

The high tide occurs when one side of the Earth is the closest or furthest away from the moon. The low tide occurs when that side of the planet is in between those points. the Mariana Trench in the Pacific Ocean, at 10,994 m deep. Fish living there, like the Mariana snailfish, have the superpower of resisting the freezing temperature and crushing pressure of $11 \mathrm{~km}$ of water on top of them. They also live their lives in total darkness [1].

In the African savannah, you can find the incredible turquoise killifish living in small, shallow pools that form when it rains. Rainwater awakens the eggs that were kept protected in the soil since the previous rainy season. Once awake, the eggs hatch. Their superpower allows the turquoise killifish to hatch from their eggs only when the environmental conditions are perfect [2].

Fish also have a superpower called osmoregulation [3]. Like humans, fish need to keep the right amount of water, salts, and nutrients in their cells. Without this superpower, fish living in the ocean would lose water from their cells and die, because the ocean has much more salt than fish tissues do. Fish living in rivers, called freshwater fish, have the opposite problem. Without osmoregulation, too much water would enter their cells and cause the cells to burst. Usually, fish that live in freshwater cannot use osmoregulation in the ocean, and the other way around. Yet, a few fish species can live in ecosystems where the salinity-the amount of salt in the water-is constantly changing. This is what happens in estuaries. Here, fish species push their osmoregulation superpower to the limit!

\section{TIDES STIR THE SALT IN ESTUARIES}

Estuaries are the final sections of rivers before they meet the ocean. Here, the water is brackish, which means that it is not as salty as the ocean, nor as fresh as in rivers. Salinity varies a lot in estuaries because tides mix the water from rivers with water from the ocean [4]. In most estuaries, the water is saltier as you get closer to the ocean. During low tide, salinity is at its minimum in the estuary because the water coming from rivers pushes estuary water out to the ocean. During high tide, salinity is at its maximum because salty ocean water enters the estuary (Figure 1). Salinity in estuaries may also vary a lot due to weather. If it rains or snows a lot in one season or during a certain year, the estuary will become less salty than usual. But if it does not rain or snow as much as normal, the estuary will become saltier.

Fish living in estuaries must adapt to the constant changes in salinity. Living in estuaries is difficult for fish! Only those species that push their osmoregulation superpower to the limit can live in estuaries. Yet, for these fish, estuaries are a happy place to live [5]!

\section{ESTUARIES: NURSERIES FOR FISH}

Most estuaries around the world are unhealthy because they are surrounded by cities, factories, and harbors. Worldwide, 2.4 
Figure 1

Estuaries during high tide and low tide. During high tide, ocean water enters the estuary, increasing the salinity and water depth. During low tide, the ocean retreats and fresh water from rivers is pulled downstream, decreasing salinity and water depth (Image credit: IAN Symbol Libraries; https://ian.um ces.edu/symbols)

\section{NURSERY}

Ecosystem that provides increased protection and food for the development of most young fish in a population.

MARSH

Shallow aquatic habitat that surrounds estuaries and coastal lagoons. It has vegetation that is adapted to salty water. In tropical regions, mangroves are the equivalent habitat to marshes.

\section{MIGRATORY FISH}

Fishes that need to move between different habitats during specific phases of their life to reproduce, feed, grow, and/or find refuge from predators.

\section{HIGH TIDE}
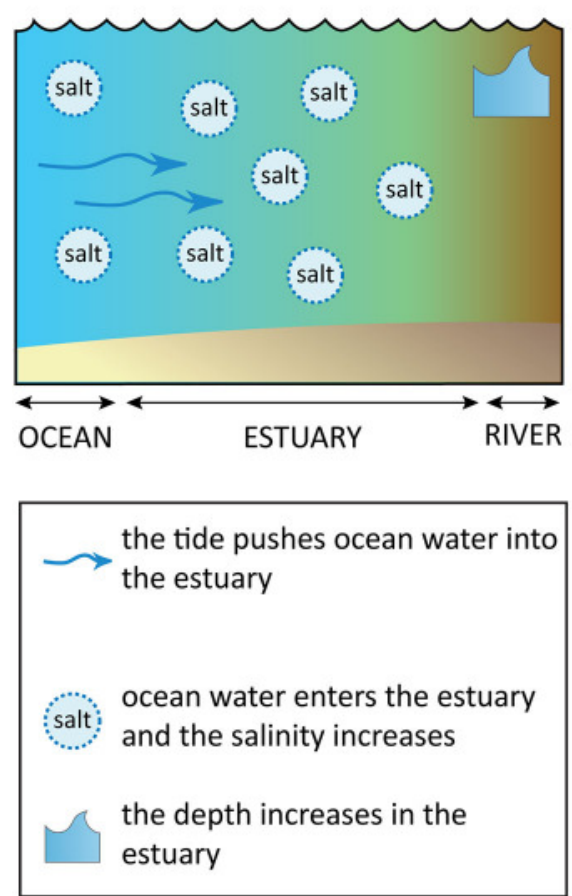

\section{LOW TIDE}
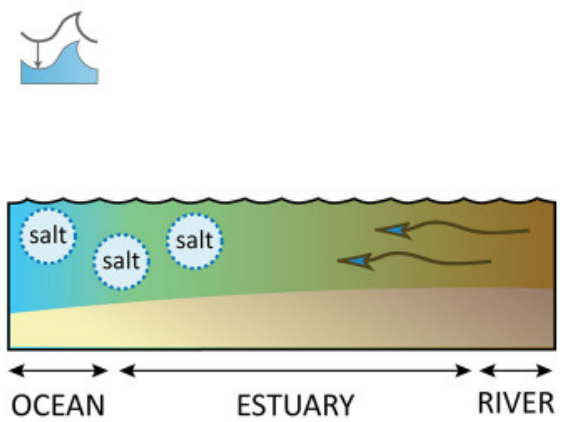

the tide pulls water from the

$\sim$ estuary to the ocean and freshwater enters the estuary

more freshwater enters the estuary and salinity decreases

the depth decreases in the estuary

billion people live within $100 \mathrm{~km}$ of the ocean, very close to estuaries. However, healthy estuaries can be wonderful places for fish to live.

Estuaries are the perfect nursery for many fish species [6]. Estuaries allow young fish to grow strong and healthy because food is abundant and diverse. The greenish or brownish color of the water makes it difficult for predators to see young fish. In an estuary's streams and marshes, young fish can also find excellent hideouts from big predators and refuge from strong currents.

Conditions in estuaries can be so good that fish migrate from the ocean into the estuaries and nearby rivers to reproduce, like the Pacific lamprey in the San Francisco Estuary. Then, larvae and juveniles will grow up there before migrating to the ocean [7]. This species belongs to a group of migratory fish called anadromous fish [7]. Other migratory fish have a different strategy, like the American eel. This species migrates to estuaries when they are larvae or juveniles because they can grow faster and stronger than they could in the ocean [7]. They migrate back to the ocean once it is time to reproduce. The American eel was introduced into the San Francisco Estuary but failed to establish a population. This species belongs to a group of migratory fish called catadromous fish.

Other species even live their entire lives in estuaries, so they are called estuarine residents. This is the case of the tule perch in the San 
Figure 2

Examples of fish species that live in the San Francisco Estuary and adjacent ecosystems. The American eel is an exception because, after being introduced, it failed to establish a population in the Estuary (Photo credits: BioDiversity4All.org).
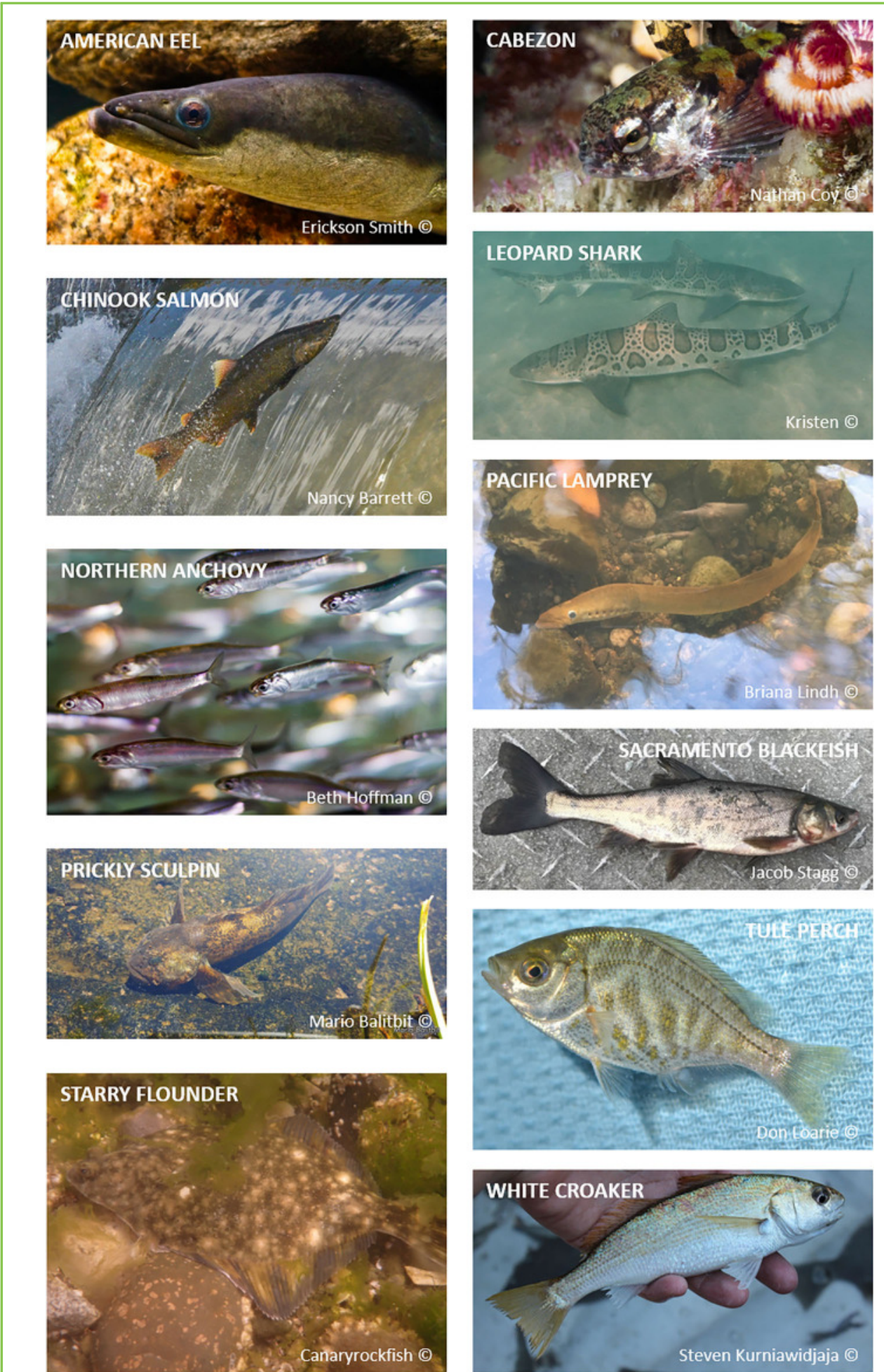

Figure 2

Francisco Estuary [8]. Other species may sometimes use estuaries as nurseries, like the leopard shark [9]. This species is called estuarine facultative [5]. Pictures of various fish species that live in the San Francisco Estuary can be seen in Figure 2. 
ECOLOGICAL NICHE

Conditions that exist in an ecosystem that allow a species to live. Usually, temperature, salinity, depth, or food preferences are used to describe the ecological niche of fish.

\section{ZOOPLANKTON}

Tiny animals that live in the water. Some resemble miniature shrimp, crabs, or snails, and you need a magnifying lens to see them properly.

\section{WHY DO FISH AVOID THEIR NEIGHBORS?}

Although it seems there is plenty of space and food in estuaries, along with secret hideouts where fish can hide from predators, each species avoids eating the same kinds of food as other species, and species also avoid living in the same place at the same time [5]. These behaviors are a brilliant strategy to decrease competition, particularly when food or space becomes scarce.

Scientists can determine how much competition exists between species by studying their ecological niche, which is the fancy expression for the types of conditions that a species likes [10]. The ecological niche of a fish includes the water temperature, salinity, or types of sediment it prefers, like sand or mud. The ecological niche may also include the food a species likes. In the San Francisco Estuary, you can find fish that always live in the rivers or the upper part of the Estuary where the water is not salty, such as the Sacramento blackfish. There are also fish that can live either in freshwater or in the brackish part of the Estuary, like the prickly sculpin. Other species only live in the brackish part of the Estuary, like the cabezon. So, you can deduce that Sacramento blackfish and cabezon will never compete for food or space because they never live in the same place. This means that their ecological niche is completely different.

But when species do live in the same place, their ecological niche may overlap. However, fish can still avoid competition. They might eat different foods or live at different depths. For example, there are benthic species that lay on the bottom most of their lives, pelagic species that are always swimming, and demersal species that live in both places. So, let us examine three species-Northern anchovy, starry flounder, and white croaker-that live in the brackish part of the San Francisco Estuary to see how much competition exists between them (Figure 3). The starry flounder is a benthic species as juveniles and adults, that eats worms, small crabs, and small clams. The Northern anchovy is a pelagic species that only eats zooplankton. So, the competition between starry flounder and Northern anchovy is very low. On the other hand, the white croaker is a demersal species. It spends time swimming around and going down to the bottom to eat clams, crabs, shrimp, or worms. So, the ecological niche of the white croaker and Northern anchovy do not overlap much because they spend only a little time in similar places. However, the competition between starry flounder and white croaker is greater because they like eating similar things that live near the bottom.

\section{PROTECTING FISH IN ESTUARIES AND ELSEWHERE}

Fish living in the San Francisco Estuary have seen better days [11]. Some species are in danger of extinction. This is the case of the delta smelt, which live their entire lives in the Estuary and other nearby 


\section{Figure 3}

Ecological niche overlap between three fish species that live in the San Francisco Estuary. Here, we determined competition between fish species by analyzing (A) habitat preference and (B) food preference.

Competition between starry flounder and Northern anchovy is low because they live in different areas and do not eat the same foods. There is only a little competition between Northern anchovy and white croaker, because they share space but not prey. The competition between white croaker and starry flounder can be greater because they eat the same prey (Image credit: IAN Symbol Libraries; https://

ian.umces.edu/symbols).

\section{A - HABITAT PREFERENCES}

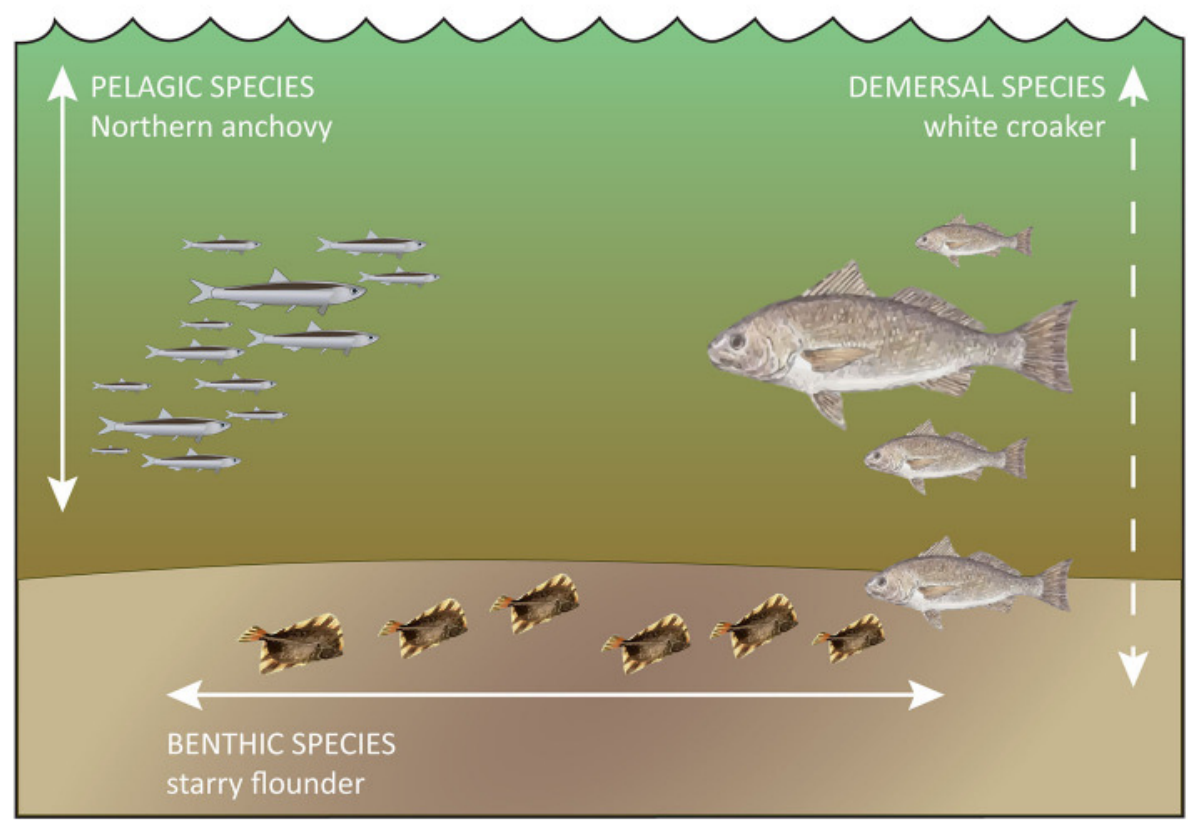

B - FOOD PREFERENCES

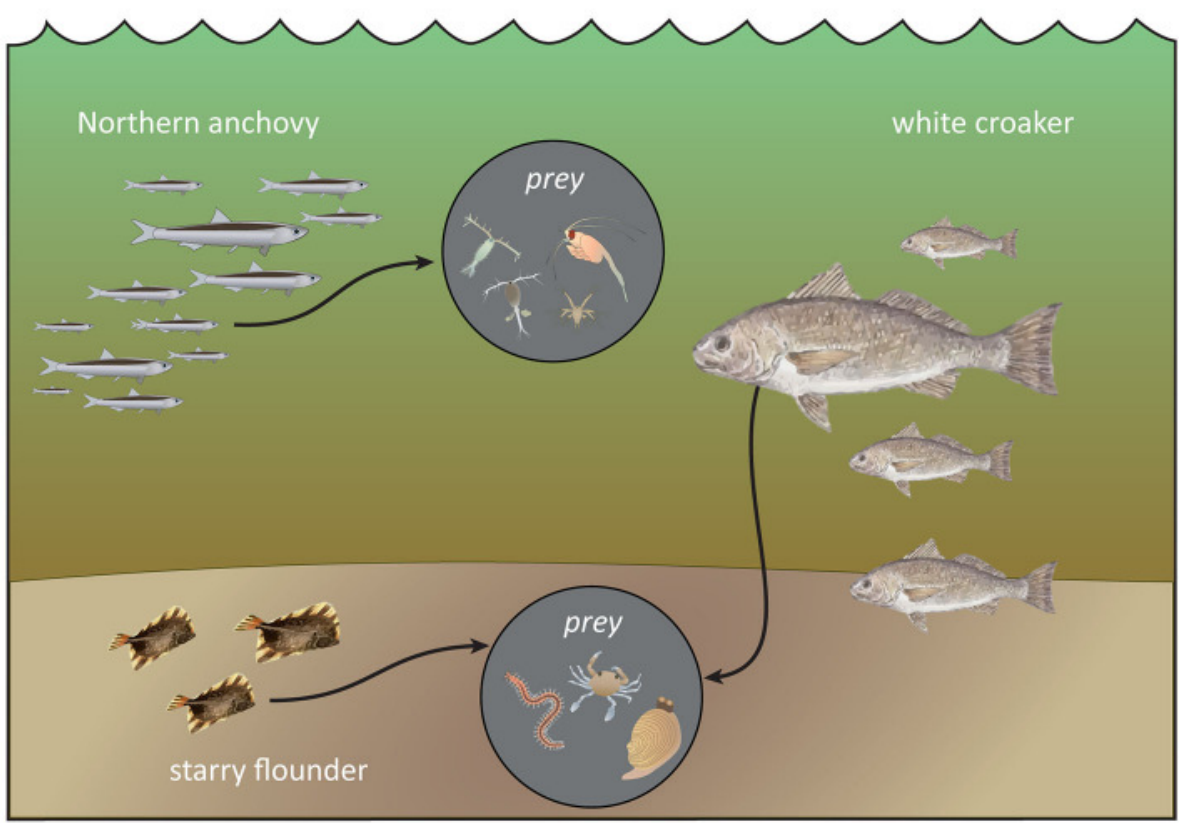

Figure 3

ecosystems, or of the winter-run Chinook salmon, which only spend a few weeks in the Estuary at the most. These species are in danger from water pollution, overfishing, invasive species, destruction of marshes and shorelines, dams, and climate change-the same reasons that many fish species all over the world are in danger.

Protecting fish and other wildlife may seem, at times, a lost cause. But people are becoming more mindful of the environment. More and more people avoid wasting good water in their homes. Others 
work to establish agricultural practices that do not use pesticides or fertilizers that can harm the environment. Other people choose to use clean, renewable energy in their homes, and some deliver dangerous chemicals to recycling centers instead of pouring them down the drain.

If you want to protect fish and other wildlife, you can start by sharing this article with your family, friends, and teachers. Make a list of your ideas about how to protect the animals and plants from your region. Find people with the same goals. Write or talk with the mayor of your city or village. Let everyone know that a healthy environment is important for all living creatures on the planet and that we need to protect them before it is too late.

\section{REFERENCES}

1. Linley, T. D., Stewart, A. L., McMillan, P. J., Clark, M. R., Gerringer, M. E., Drazen, J. C., et al. 2017. Bait attending fishes of the abyssal zone and hadal boundary: community structure, functional groups and species distribution in the Kermadec, New Hebrides and Mariana trenches. Deep Sea Res Part Oceanogr Res Pap. 121:38-53. doi: 10.1016/j.dsr.2016.12.009

2. Reichard, M., and Polačik, M. 2019. The natural history of model organisms: Nothobranchius furzeri, an 'instant' fish from an ephemeral habitat. eLife. 8:e41548. doi: 10.7554/eLife.41548

3. McCormick, S. D. 2001. Endocrine control of osmoregulation in teleost fish. Am. Zool. 41:781-94. doi: 10.1093/icb/41.4.781

4. Morais, P. 2007. The Life Cycle of Engraulis encrasicolus sensu lato in the Guadiana Estuary: Ecology, Ecohydrology and Biology (Ph.D). FCMA, Faro: University of Algarve.

5. Chícharo, M. A., Chícharo, L., and Morais, P. 2006. Inter-annual differences of ichthyofauna structure of the guadiana estuary and adjacent coastal area (SE Portugal/SW Spain): before and after alqueva dam construction. Estuar Coast Shelf Sci. 70:39-51. doi: 10.1016/j.ecss.2006.05.036

6. Faria, A., Morais, P., and Chícharo, M. A. 2006. Ichthyoplankton dynamics in the Guadiana estuary and adjacent coastal area, South-East Portugal. Estuar Coast Shelf Sci. 70:85-97. doi: 10.1016/j.ecss.2006.05.032

7. Morais, P., and Daverat, F. 2016. “Definitions and concepts related to fish migration," in An Introduction to Fish Migration, eds P. Morais, and F. Daverat (Boca Raton, FL: CRC Press), 14-9.

8. Matern, S. A., Moyle, P. B., and Pierce, L. C. 2002. Native and alien fishes in a California estuarine marsh: twenty-one years of changing assemblages. Trans Am Fish Soc. 131:797-816. doi: 10.1577/1548-8659(2002)131<0797:NAA $\mathrm{FIA}>2.0 . \mathrm{CO} ; 2$

9. Fichman, R. A., Khen, A., Willmes, M., Kuntz, J., Scott, A. R., Hobbs, J.A., et al. 2021. The clever strategies fishes use to survive in San Francisco's dynamic estuary. Front Young Minds.

10. Costalago, D., Palomera, I., and Tirelli, V. 2014. Seasonal comparison of the diets of juvenile European anchovy Engraulis encrasicolus and sardine Sardina 
pilchardus in the gulf of lions. J. Sea Res. 89:64-72. doi: 10.1016/j.seares.20 14.02.008

11. Moyle, P. 2008. The future of fish in response to large-scale change in the San Francisco Estuary, California. Am Fish Soc Symp. 64:357-74. https://www. researchgate.net/publication/228626736_The_future_of_fish_in_response_ to_large-scale_change_in_the_San_Francisco_Estuary_California

SUBMITTED: 04 October 2020; ACCEPTED: 07 September 2021; PUBLISHED ONLINE: 07 October 2021.

EDITED BY: Frederique Carcaillet, Université de Montpellier, France

CITATION: Morais P and Dias E (2021) Estuaries, A Happy Place For Fish. Front. Young Minds 9:613862. doi: 10.3389/frym.2021.613862

CONFLICT OF INTEREST: The authors declare that the research was conducted in the absence of any commercial or financial relationships that could be construed as a potential conflict of interest.

COPYRIGHT () 2021 Morais and Dias. This is an open-access article distributed under the terms of the Creative Commons Attribution License (CC BY). The use, distribution or reproduction in other forums is permitted, provided the original author(s) and the copyright owner(s) are credited and that the original publication in this journal is cited, in accordance with accepted academic practice. No use, distribution or reproduction is permitted which does not comply with these terms.

\section{YOUNG REVIEWER}

\section{FRESIA, AGE: 11}

I love science and math, but I am not a fan of history and geography. My big passion is animals. I have a snake named Sacha jr. and a rabbit named Luna, and I love to raise silkworms and search for lizards and other animals in the wild. I am also learning to ride horses and I love using creativity to make crafts.

\section{AUTHORS}

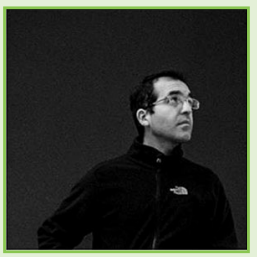

\section{PEDRO MORAIS}

My passion for marine biology began when I was 7 years old. I went on vacation with my parents and sister to a lovely beach in southern Portugal. There, I spent all the time I could in the tide pools searching for fishes, crabs, shrimps, and anemones. I have studied all kinds of aquatic organisms (bacteria, microscopic algae, jellyfish, clams, crabs, birds, fish, and even whales and dolphins) from the deep ocean to shallow lagoons, estuaries, rivers, lakes, and streams. During my free time, I enjoy dancing tango, taking photographs, woodworking, fixing and restoring old things, and researching my ancestry. *pmorais@ualg.pt 


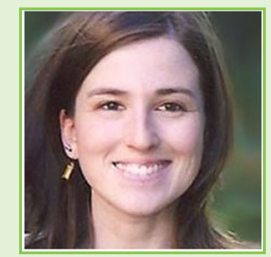

\section{ESTER DIAS}

I am a researcher at the Estuarine Ecology and Biological Invasions research group (CIIMAR-University of Porto, Portugal). As a child, I was curious about how animals behave, what they eat, and why they need to migrate long distances to reproduce. So, becoming a biologist was my chance to find the answer to these questions. So far, I have studied small aquatic animals called zooplankton (some only $1 \mathrm{~mm}$ in size), clams, aquatic birds, fish, and even marine mammals. Currently, I study the migrations of fish, the impacts of biological invasions, and what is on the menu of each aquatic species. 